\title{
Would Sacaca, Croton cajucara Benth (Euphorbiaceae) be an hepatotoxic plant like Germander, Teucrium chamaedrys L. (Labiatae)?
}

\author{
Será a Sacaca, Croton cajucara Benth (Euphorbiaceae) uma planta hepatotóxica \\ semelhante à Germander, Teucrium chamaedrys L ( Labiatae)?
}

\author{
Manoel do Carmo Pereira Soares ${ }^{1}$
}

\begin{abstract}
Clinical and experimental studies have consistently incriminated the medicinal plant germander (Teucrium chamaedrys L) in epidemic and sporadic cases of liver diseases. The sacaca (Croton cajucara Benth), a common plant in Brazilian Amazon region also comes being incriminated in similar clinical cases. Of both plants were isolated diterpenoid coumpounds with similar chemical structures.
\end{abstract}

Key-words: Sacaca. Croton cajucara. Germander.

\section{RESUM0}

Estudos clínicos e experimentais tem incriminado, de forma consistente, na França, a planta medicinal germander (Teucrium chamaedrys L) em casos esporádicos ou epidêmicos de hepatopatias. A Sacaca (Croton cajucara Benth), uma planta comum na Amazônia brasileira, também vem sendo incriminada em casos clínicos semelhantes. De ambas as plantas, foram isolados diterpenóides com estruturas químicas semelhantes.

Palavras-chaves: Sacaca. Croton cajucara. Germander.

Clinical and experimental studies have consistently incriminated the medicinal plant germander (Teucrium chamaedrys L) in epidemic and sporadic cases of acute hepatitis as well as in fulminant, chronic hepatitis and cirrhosis ${ }^{8}$. Germander has been used in Europe since ancient times as a folk medicine. Aerial parts of the plant in bloom were used to prepare herbal teas used in the assumption of having choleretic and antiseptic properties. The plant was in general regarded as harmless. Nevertheless, in 1986, when was marketed in France as an adjuvant to slimming diets resulted in an epidemic of hepatitis in that country ${ }^{8}$. Germander contains furano neo-clerodane diterpenoids which has been shown to induce hepatotoxicity ${ }^{5}$.

Sacaca (Croton cajucara Benth) is a common shrub in the Brazilian Amazon region that grows in mainland. Rural communities use its bark and leaf in the preparation of a tea to treat diarrhea, diabetes, liver and kidney disturbs ${ }^{9}$. Because of its properties in decreasing cholesterolemia and weight control its use has incresead among urban populations. It has been used under various presentations such as teas or capsules containing sacaca powder. Recent reports have attributed to sacaca coumpounds both antiulcerative and hypoglycemiantproperties ${ }^{13}$. On the other hand, in $1991 \mathrm{Kubo} \mathrm{et} \mathrm{al}^{4}$ have published the isolation of a new diterpenoid (cisdehydrocrotonin) together with the known nor-diterpene transdehydrocrotonin, both extracted from the bark of sacaca came from Brazilian Amazon and, these authors, aware its popular use, performed an in vitro assay to evaluate the extract antihepatotoxic activity. Paradoxically, however, itshowed potenthepatotoxic activity".

Exemplar chemical structures of diterpenoids isolated from both Teucrium chamaedrys and Croton cajucara are shown in Figure 1. Both plant species contain others furano diterpenoid coumpounds ${ }^{4}$.

Some published and unpublished observations have recently implicated sacaca in cases of liver injury in Amazon region ${ }^{2}$, mainly after it was marketed as an adjuvant for weight control and cholesterolemia level decrease. It has been incriminated in acute, fulminant and chronic hepatitis. In a recent 36 month study, Cartágenes et a ${ }^{2}$ reported 25 cases of liver disease attributed to sacaca hepatotoxicity: 21 patients had acute hepatitis, three had chronic hepatitis and one developed fulminant hepatitis².

1. Instituto Evandro Chagas da Secretaria de Vigilância em Saúde do Ministério da saúde.

Endereço para correspondência: Dr. Manoel do Carmo Pereira Soares. Av. Almirante Barroso 492, 66090-000. Belém, PA Brazil.

Fax: 91 241-4418, 91 226-12 84

e-mail: msoares@iec.pa.gov.br 


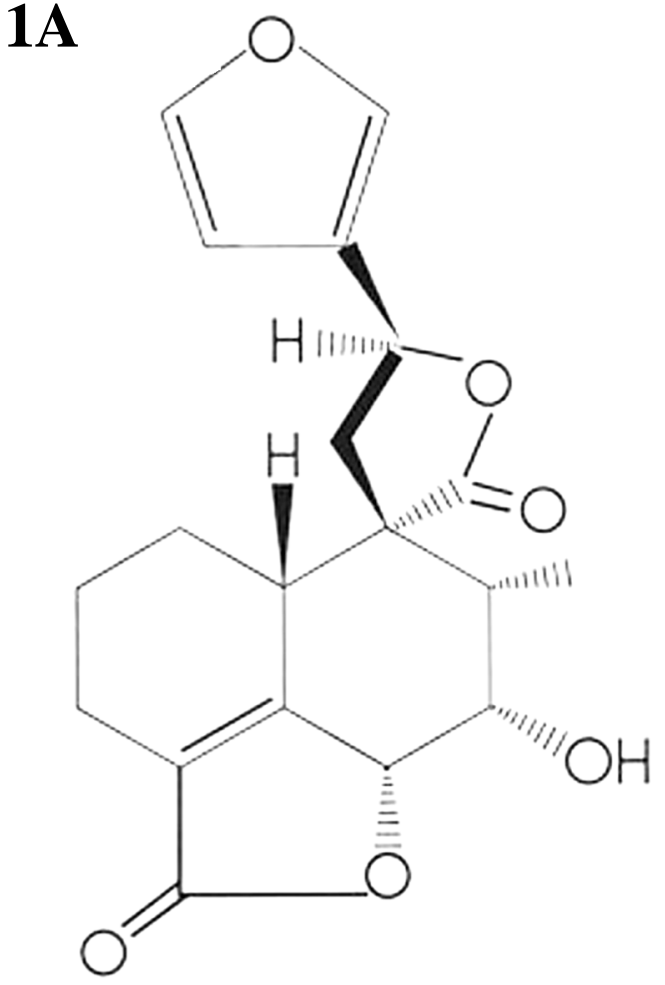

Teucrin A

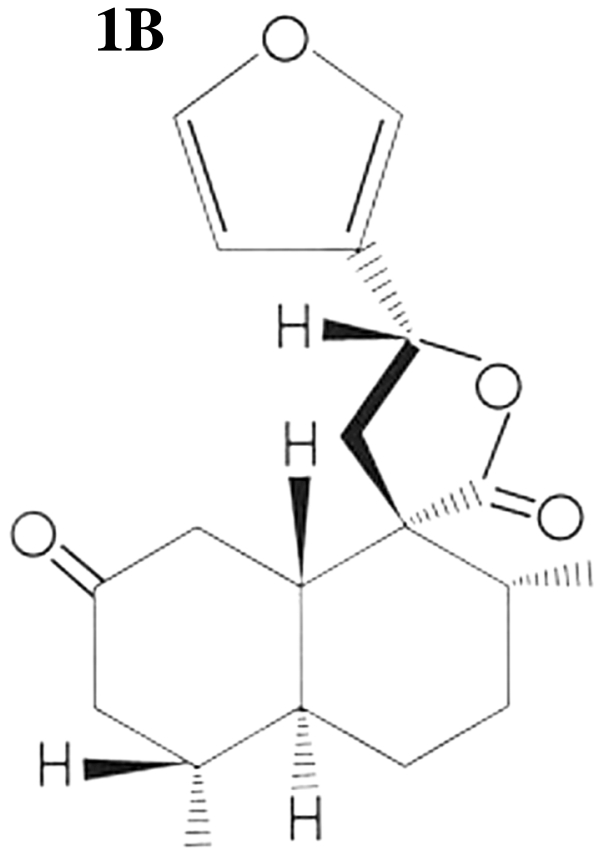

Crotonin

Figure 1 - Chemical structure of the Teucrin A and Cretonin, furano diterpenoids isolated from both Teucrium chamaedrys (1A) and Croton cajucara (1B).

Sacaca and germander have similar chemical structures for their furano diterpenoids. Since Amazonian herbal medicines have obtained growing interest throughout the world, cautions should be exercised in regards to their potential toxic effects.

\section{REFERENCES}

1. Brito AR, Rodríguez JA, Hiruma Lima CA, Haun M, Nunes DS. Antiulcerogenic activity of trans-dehydrocrotonin from Croton cajucara. Planta Medicine 64: 126-129, 1998.

2. Cartágenes PRB, Moreira $C$, Teixeira AC, Silveira FAA, Dias-Junior $\mathrm{LB}$, Bichara CDA. Hepatite por sacaca (Croton cajucara Benth): Epidemiologia clínica em 25 casos [ resumo]. Gastroenterologia Endoscopia Digestiva 18 ( supl 1): 24, 1999.

3. Farias RA, Rao VS, Viana GS, Silveira FR, Maciel MA, Pinto AC. Hypoglycemic effect of trans-dehydrocrotonin, a nor-clerodane diterpene from Croton cajucara. Planta Medicine 63: 558-560, 1997.
4. Kubo I, Asaka Y, Shibata K. Insect growth inhibitory nor-diterpenes, cisdehydrocrotonin and trans-dehydrocrotonin, from Croton cajucara. Phytochemistry 30: 2545-2546, 1991.

5. Larrey D. Hepatotoxicity of herbal remedies. Journal of Hepatology 26 ( supl 1) : 47-51,1997.

6. Larrey D, Vial T, Pauwels A, Castot A, Biour M, David M, Michel H. Hepatitis after germander (Teucrium chamaedrys) administration: another instance of herbal medicine hepatotoxicity. Annals International Medicals 117: 129-132, 1992.

7. Lekehal M, Pessayre D, Lereau JM, Moulis C, Fourast F, Fau D. Hepatotoxicity of the herbal medicine germander. Metabolic activation of its furano diterpenoids by cytochrome P450 3A depletes cytoskeletonassociated protein thiols and forms plasma membrane blebs in rat hepatocytes. Hepatology 24: 212-218, 1996.

8. Mostefa-Kara N, Pauwels A, Penes E, Biour M, Levy VG. Fatal hepatitis after herbal tea. Lancet 340: 674, 1992.

9. Vieira LS. Fitoterapia da Amazônia: Manual das Plantas Medicinais, 2ª edição, Agronômica Ceres, São Paulo, 1992. 